\title{
Greenhouse gas emission of diets in the Netherlands and associations with food, energy and macronutrient intakes
}

\author{
Elisabeth HM Temme ${ }^{1, *}$, Ido B Toxopeus ${ }^{1}$, Gerard FH Kramer ${ }^{2}$, Marinka CC Brosens ${ }^{1}$, \\ José MM Drijvers ${ }^{1}$, Marcelo Tyszler ${ }^{2}$ and Marga C Ocké ${ }^{1}$ \\ ${ }^{1}$ National Institute for Public Health and the Environment (RIVM), PO Box 1, 3720 BA Bilthoven, The Netherlands: \\ ${ }^{2}$ Blonk Consultants, Gouda, The Netherlands
}

Submitted 14 March 2014: Final revision received 26 September 2014: Accepted 31 October 2014: First published online 29 December 2014

\begin{abstract}
Objective: To evaluate the greenhouse gas emission (GHGE) of diets in Dutch girls, boys, women and men and to explore associations with diet composition. Design: Descriptive analyses for the total population as well as stratified for gender, age and dietary environmental load.

Setting: The Netherlands.

Subjects: Dutch children and adults aged 7-69 years ( $n$ 3818).

Results: The GHGE of daily diets was on average $3 \cdot 2 \mathrm{~kg} \mathrm{CO}_{2}$-equivalents $\left(\mathrm{CO}_{2} \mathrm{e}\right)$ for girls, $3.6 \mathrm{~kg} \mathrm{CO} 2 \mathrm{e}$ for boys, $3.7 \mathrm{~kg} \mathrm{CO}_{2} \mathrm{e}$ for women and $4.8 \mathrm{~kg} \mathrm{CO} \mathrm{CO}_{2} \mathrm{e}$ for men. Meat and cheese contributed about $40 \%$ and drinks (including milk and alcoholic drinks) $20 \%$ to daily GHGE. Considerable differences in environmental loads of diets existed within age and gender groups. Persons with higher-GHGE diets consumed more (in quantity of foods and especially drinks) than their counterparts of a similar sex and age with low-GHGE diets. Major differences between high- and low-GHGE diets were in meat, cheese and dairy consumption as well as in soft drinks (girls, boys and women) and alcoholic drinks (men). Of those, differences in meat consumption determined the differences in GHGE most. Diets with higher GHGE were associated with higher saturated fat intake and lower fibre intake

Conclusions: GHGE of daily diets in the Netherlands is between 3 and $5 \mathrm{~kg} \mathrm{CO}_{2} \mathrm{e}$, with considerable differences between individuals. Meat, dairy and drinks contribute most to GHGE. The insights of the study may be used in developing (age- and gender-specific) food-based dietary guidelines that take into account both health and sustainability aspects.
\end{abstract}

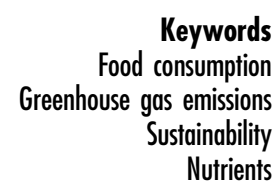

The rising concern about global food security and climate change has led to an increased interest in sustainable and healthy diets ${ }^{(1-4)}$. Typically, food drives $20-30 \%$ of the life-cycle environmental impacts of final household consumption $^{(5)}$. To reduce the current burden of food consumption on the environment, food consumption patterns need to change ${ }^{(6,7)}$.

The FAO defines sustainable diets as 'diets protective and respectful of biodiversity and ecosystems, culturally acceptable, accessible, economically fair and affordable; nutritionally adequate, safe and healthy; while optimizing natural and human resources, ${ }^{(8)}$. Accordingly, the FAO recommends giving due consideration to sustainability when developing food-based dietary guidelines and policies, acknowledging the need for studies demonstrating the synergies between the different dimensions of sustainability $^{(8)}$. The Health Council of the Netherlands, in addition, considers it as important to evaluate synergies between environmental load and health and to identify targets for interventions to lower the environmental load of diets ${ }^{(9)}$.

Ecological or environmental indicators are used to evaluate the impact of human activity on ecosystems. The environmental pressure indicator, greenhouse gas emission (GHGE), has been applied in most previous research papers and can be considered a good proxy for this total environmental load ${ }^{(10)}$. The European Commission set a goal to reduce GHGE by at least $20 \%$ by 2020 . GHGE covers $\mathrm{CO}_{2}$ emissions from fossil fuels, $\mathrm{CH}_{4}$ released during the rearing of cattle and the cultivation of certain crops, and $\mathrm{N}_{2} \mathrm{O}$ released from fertilizers, manure and ploughing of grassland ${ }^{(1,11)}$. GHGE is expressed as $\mathrm{kg}$ $\mathrm{CO}_{2}$-equivalents $\left(\mathrm{CO}_{2} \mathrm{e}\right)$. GHGE for a day's consumption was estimated to be 4.7 ( $\mathrm{SD} 1.2$ ) $\mathrm{kg} \mathrm{CO}_{2} \mathrm{e}$ for men and 
3.7 (SD 0.9) $\mathrm{kg} \mathrm{CO}_{2} \mathrm{e}$ for women in a population-based survey in France ${ }^{(12)}$. In Western diets, meat and dairy are the most important contributors to $\mathrm{GHGE}^{(5,7,13-16)}$. Changing from a meat- and dairy-based diet towards a more plantbased diet may reduce GHGE by $20-35 \%$ on a daily basis $^{(17-19)}$. It is less clear what the associations between GHGE and macro- and micronutrient intakes are. Modelling studies show that changing currently consumed diets to diets in accordance with guidelines for healthy nutrition reduces GHGE by about $8 \%{ }^{(15)}$ to $36 \%^{(20)}$. Vieux et al. ${ }^{(21)}$, on the other hand, reported results that seem to contradict these findings. Self-selected diets of French adults with the highest nutritional quality scores tended to have a high level of diet-related GHGE as well ${ }^{(21)}$. Obviously, this area of research needs more studies providing insight into the relationships between environmental loads of diets and food and nutrient intakes in real-life settings. Moreover, since children have different consumption patterns and nutritional requirements compared with adults, such associations might be different for adults and children. To our knowledge, no previous studies have calculated the environmental impact of children's diets.

The aims of the present study were therefore to evaluate the GHGE of diets in Dutch girls, boys, women and men separately and to explore associations with diet composition, total (food and energy) intake and macronutrient intakes. The insights from the study may be used in developing (age- and gender-specific) food-based dietary guidelines that take into account both health and sustainability aspects.

\section{Methods}

\section{Study population}

Consumption data were from the most recent food consumption survey, the Dutch National Food Consumption Survey (DNFCS) 2007-2010 (22), among Dutch children and adults aged 7-69 years. The food consumption of 3819 people was measured on two non-consecutive days, by means of a $24 \mathrm{~h}$ dietary recall, in a representative sample of the Dutch population. One individual consuming only meal replacers (for weight reduction) was excluded from the present analyses. Calculations are thus based on 3818 individuals.

The target population comprised all men and women living in the Netherlands between the ages of 7 and 69 years. Pregnant and lactating women, people who were institutionalized and those without adequate command of the Dutch language were excluded. Participants were drawn from representative consumer panels of the market research agency GfK. The market research agency invited selected persons by either post or email to participate in the study. Those who agreed to participate were sent the general questionnaire. Contact with children between the ages of 7 and 15 years was made initially through their parents or carers. The overall response was $69 \%$.

\section{General questionnaire}

The questions in the general questionnaire covered various sociodemographic and lifestyle factors such as physical activity, education level and income. Data from the questionnaires were checked for impossible values, inconsistencies and missing values. Information on educational level was combined and/or aggregated into low, middle and high. The highest educational level of the respondent - or, in case of those aged 7-18 years, the highest educational level of their parents or carers - was defined. The information on physical activity was obtained according to the Squash (Short QUestionnaire to ASses Health enhancing physical activity) questionnaire for adolescents and adults ${ }^{(23)}$. Questions on physical activity included activities at work/school, household activities and activities during leisure time. Respondents were asked to state per activity how many days they performed the activity, how many hours per day and what the intensity of the activity was (the question on intensity was available only for adults). In the questionnaires for children (7-11 years) and adolescents (12-18 years) questions on activities more relevant for these age groups were included; for example, questions referring to watching television, computer time, sports at school, walking or cycling to school, sports club activities and playing outdoors. Based on the information in the questionnaires, time spent on physical activities was taken together (based on the manual from Squash) and calculated in MET $\times \mathrm{h} /$ week $^{(22)}$. MET are metabolic equivalents to assess physical activity levels. General information about the participant (such as self-reported height and weight) was assessed in the food consumption interview. Based on the information on both interview days, the average body weight and height were calculated. BMI was determined as the average body weight (in kilograms) divided by average height (in metres) squared $\left(\mathrm{kg} / \mathrm{m}^{2}\right)$. Estimates of BMR were calculated from standard equations based on weight, age and $\operatorname{sex}^{(24)}$.

\section{Dietary assessment}

For the dietary assessment, participants aged 16-69 years were interviewed by telephone by a trained dietitian, on two separate days and at times unknown to the participants. The interview was about the day before the interview $(24 \mathrm{~h}$ recall). The $24 \mathrm{~h}$ period started in the morning on the day before the $24 \mathrm{~h}$ recall and continued until the following day when the person got up (the day on which the interview was held). Food consumption on Saturday was recalled on the following Monday. The two $24 \mathrm{~h}$ food recalls for children between the ages of 7 and 15 years were compiled by means of face-to-face interviews during home visits. The child's parents were also present during this interview. Each person was interviewed twice with an interval of about 4 weeks between the interviews. The aim was that all recalled days of the week were equally represented. 
The dietitians used the computer-controlled interview software EPIC-Soft ${ }^{\circledR}$ (C) International Agency for Research on Cancer) ${ }^{(22)}$. With EPIC-Soft answers were directly entered into a computer ${ }^{(25)}$.

\section{Energy and macronutrient composition}

Composition data were already linked to food consumption data via 1599 NEVO food codes. Energy and macronutrient intakes were calculated using an extended version of the Dutch food composition database (NEVO table $2011 / 3 \cdot 0)^{(26)}$.

\section{Greenbouse gas emission of foods and drinks}

To estimate GHGE of foods and drinks, life-cycle assessments (LCA) were performed for 254 food items (Blonk Consultants data set, version 2012). LCA is a technique to assess environmental loads associated with all the stages of a product's life, in this case from farm to fork. The LCA included all phases in between primary production, processing, use of packaging, transport, storage, preparing, cooking and incineration of waste products. Waste in the Netherlands is either recycled or incinerated. Landfilling of municipal waste is forbidden. Part of the organic waste is composted. We assumed waste incineration of packaging materials (plastic, drink cartons, etc.) with energy recovery, except for glass and paper, as the default waste scenario. Wasted amounts of foods were taken into account in the mass balance of the LCA analyses. Emissions and avoided emissions due to incineration and composting of food waste were not included. Foods with the highest (frequency of) consumption in the DNFCS 2007-2010 were selected for the LCA analyses. Calculation of LCA followed uniform calculation methods and current standards like those of the International Organization for Standardization (ISO 14040) and the Publicly Available Specification (PAS 2050). Life-cycle inventory data were collected from primary sources and literature preferably representative for the Dutch situation. Economic allocation was applied for co-products using agricultural statistics (of the FAO and others) and information on food processing (based on literature and additional studies). For background data, Eco-invent (http://www.ecoinvent.ch/) was used. The calculated GHGE are expressed as $\mathrm{kg}$ of $\mathrm{CO}_{2} \mathrm{e} / \mathrm{kg}$ of a certain food as consumed. The time horizon for GHGE calculations is 100 years.

An experienced dietitian extended the LCA-based GHGE database for the 254 most frequently consumed foods to the other reported food codes in the DNFCS 2007-2010. Extrapolations were based on the ingredient compositions of the foods, similarities in production system and similarities in type of food and variety. For example, for solid cheese, the available GHGE value for a certain type of solid cheese with high consumption was applied to all other types of solid cheese. For alcoholic beverages, the available GHGE value for gin was used as a value for spirits and brandy, and all beers and wines received the value from a resembling type of beer or wine. GHGE for spices, herbs and meal replacers (for weight reduction) were not included in the analysis.

\section{Environmental load, food, energy and macronutrient intakes of daily diets}

For each participant, the mean daily total amount of food and drink was calculated in grams and the GHGE, in $\mathrm{kg}$ $\mathrm{CO}_{2} \mathrm{e}$. Further analyses were carried out according to gender and age groups separately; girls and boys aged 7-18 years, and women and men aged 19-69 years. For presentation purposes, these groups were classified according to low, intermediate or high environmental load of diets averaged over two days by group-specific tertile cut-off points. This classification provided the basis for further presentation of characteristics and food, energy and macronutrient intakes.

For the analyses of gram intake per food group, we aggregated EPIC-Soft food groups: meat, fish and egg consumption were combined; potato, vegetable, legumes, pulses and fruits were combined; fat, soups and sauces were combined; and sugar, sweets and biscuits were combined $^{(22)}$. Dairy products were classified as dairy drinks, dairy desserts and cheese. Drinks were aggregated into drinks with and without alcohol (in Fig. 2); non-alcoholic drinks were subdivided into fruit and vegetable juices, soft drinks, coffee and tea, and tap water (in Figs 1 and 3).

The ratio of energy intake to physical activity level (EI: PAL) was calculated by dividing each participant's mean daily total energy intake in kilojoules by the mean physical activity level in MET $\times$ h. The ratio of energy intake to BMR (EI:BMR) was calculated for each individual and averaged per subgroup to evaluate the possibility of under- and over-reporting.

\section{Statistical methods}

To evaluate the habitual GHGE distributions of daily diets the long-term GHGE was estimated, correcting for the intra-individual variation using SPADE (Statistical Program to Assess Dietary Exposure) ${ }^{(27)}$.

For all other calculations the mean observed intakes were calculated from the two consumption days. Descriptive statistics (means and standard deviations and percentages of the population) were calculated for the total population, as well as stratified by gender and age and within these categories according to environmental load classification. Further statistical analyses were carried out within groups of girls (aged $7-18$ years), boys (aged $7-18$ years), women and men ( $>18$ years). For categorical variables, $\chi^{2}$ tests were applied to test for statistically significant differences between environmental load categories (low, intermediate and high).

To investigate the associations between GHGE of diets and continuous variables (characteristics, food and macronutrient intakes), simple general linear models (GLM procedure of the SAS statistical software package version 9.3) were applied. In the models, GHGE of the daily diet was the dependent variable and the parameter of interest 
the independent variable, and analyses were carried out by gender and age class. To increase normality we used the natural logarithm of GHGE in all models. In all models, age was included as a covariate. An $\alpha$ level of 0.05 was used to determine statistical significance.

\section{Results}

\section{Greenbouse gas emission of foods, daily diets and important food sources}

Figure 1 shows the average GHGE of foods and its standard deviation by food group. Meat and cheese had the largest impact per kilogram of food. However, variation within food groups was sometimes large; for example, within the meats, beef had a much larger impact than chicken. Of the drinks (expressed per kilogram), production of dairy drinks involved the highest GHGE.

The habitual GHGE of a day's consumption in the Netherlands was on average $3.2 \mathrm{~kg} \mathrm{CO} \mathrm{CO}_{2} \mathrm{e}$ for girls, $3.6 \mathrm{~kg}$ $\mathrm{CO}_{2} \mathrm{e}$ for boys, $3.7 \mathrm{~kg} \mathrm{CO}$ e for women and $4.8 \mathrm{~kg} \mathrm{CO}_{2} \mathrm{e}$ for men (see Table 1, columns on the right). Age- and gender-specific tertile cut-offs (percentile 33 and 66 based on two recall days) classified diets into low, intermediate and high environmental load (see Table 1, columns on the left). According to habitual intake calculations, percentile 33 was slightly higher than that based on calculations from two recall days; percentile 66 was similar.
Figure 2 depicts major foods contributing to the GHGE of daily diets. About $40 \%$ of the GHGE of daily diets stemmed from meat and cheese, with a similar percentage in girls, boys, women and men. For all age and gender groups, the contribution of drinks to daily GHGE was approximately $20 \%$. For children about half of this stemmed from dairy drinks; for adults this was about a third. Other major contributing drinks were soft drinks in girls and boys (about $0 \cdot 30 \mathrm{~kg} \mathrm{CO}_{2} \mathrm{e}$ ), brewed coffee and tea and soft drinks in adults ( $0.40 \mathrm{~kg} \mathrm{CO}_{2}$ e for women and $0.45 \mathrm{~kg} \mathrm{CO}_{2} \mathrm{e}$ for men) and alcoholic beverages in men $\left(0.25 \mathrm{~kg} \mathrm{CO}_{2} \mathrm{e}\right)$. Potatoes, vegetables and fruits contributed approximately $9 \%$ to the GHGE of daily diets.

\section{Characteristics of the population}

Tables 2 and 3 show the characteristics of girls and boys, women and men on average and for persons with diets of low, intermediate and high environmental load. Among girls, boys and women, the average person's age was higher in the high environmental load groups (the difference is 1 year for girls, 3 years for boys and women). However, for adult men ages were similar across environmental load groups. In further statistical analyses, age was included as a covariate. Environmental loads of diets were not significantly associated with (parents') education or urbanization grade of the living environment of the person.

(a)

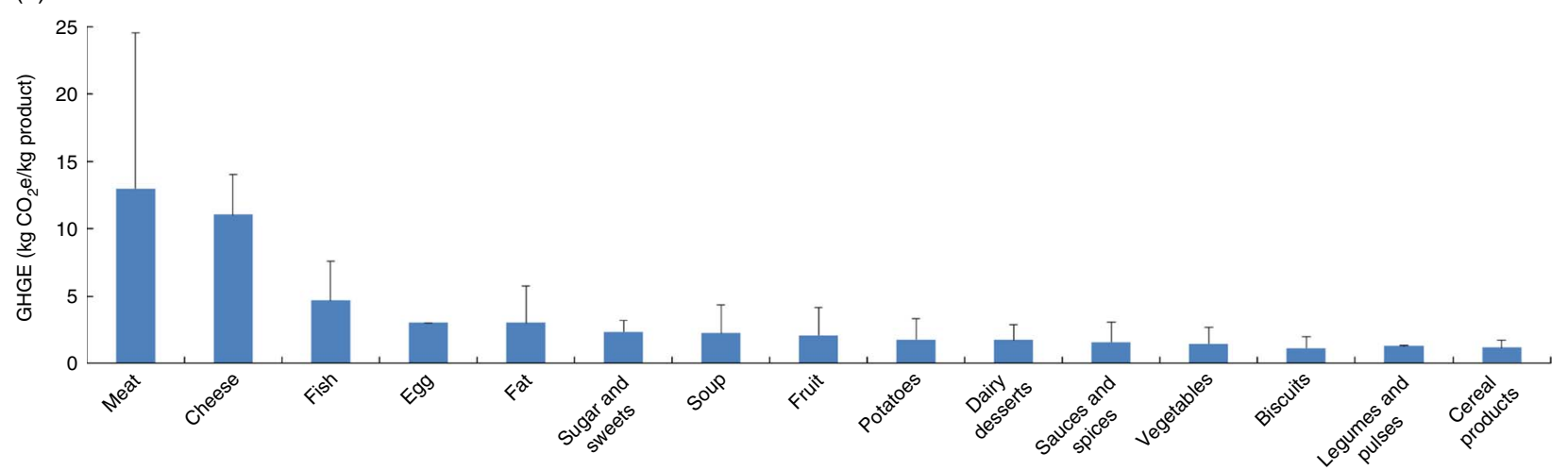

(b)

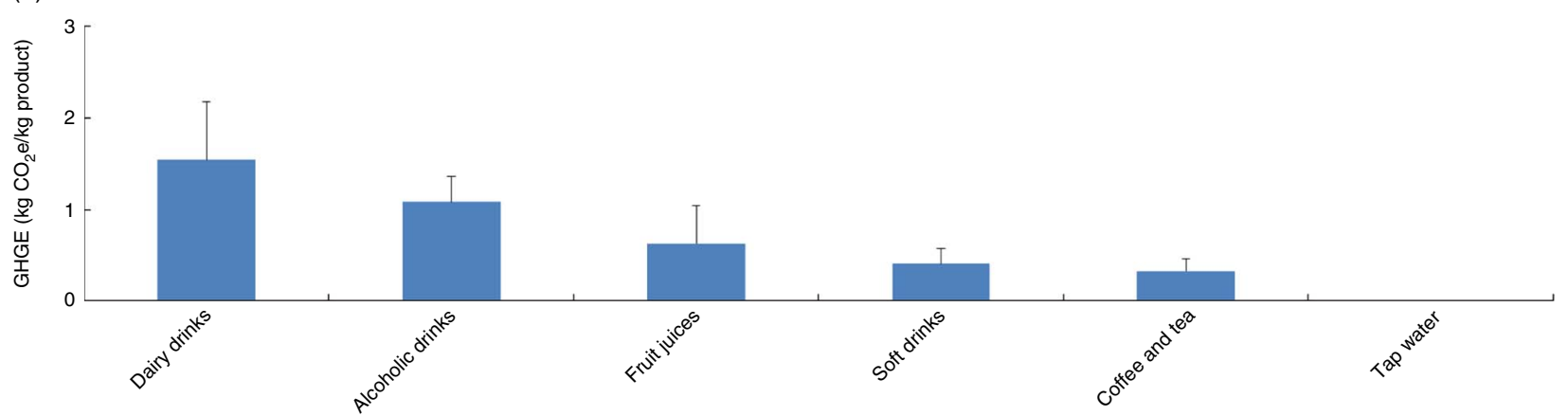

Fig. 1 (colour online) Average greenhouse gas emissions (GHGE; in $\mathrm{kg} \mathrm{CO}_{2}$-equivalents $\left(\mathrm{CO}_{2} \mathrm{e}\right) / \mathrm{kg}$ product) for different (a) food and (b) drink categories. Values are means, with their standard deviations represented by vertical bars 
Table 1 GHGE (in kg $\mathrm{CO}_{2} \mathrm{e} / \mathrm{d}$ ) for a day's consumption for Dutch girls, boys, women and men

\begin{tabular}{|c|c|c|c|c|c|c|c|c|c|c|c|c|}
\hline & \multicolumn{4}{|c|}{$\begin{array}{l}\text { GHGE for a day's consumption } \\
\text { based on two } 24 \mathrm{~h} \text { recalls } \dagger\end{array}$} & \multicolumn{8}{|c|}{ Habitual GHGE for a day’s consumption $\ddagger$} \\
\hline & Mean & SD & P33 & P66 & Mean & $95 \% \mathrm{Cl}$ & P33 & $95 \% \mathrm{Cl}$ & P50 & $95 \% \mathrm{Cl}$ & P66 & $95 \% \mathrm{Cl}$ \\
\hline Total population & 3.9 & 1.6 & 3.0 & $4 \cdot 2$ & $4 \cdot 1$ & $4 \cdot 0,4 \cdot 2$ & 3.6 & $3.5,3.6$ & 4.0 & $4 \cdot 0,4 \cdot 1$ & 4.4 & $4.4,4.5$ \\
\hline Girls (7-18 years) & 3.1 & 1.1 & $2 \cdot 6$ & 3.3 & $3 \cdot 2$ & $3 \cdot 1,3 \cdot 2$ & $2 \cdot 8$ & $2 \cdot 8,2 \cdot 9$ & $3 \cdot 1$ & $3 \cdot 0,3 \cdot 2$ & 3.4 & $3.3,3.5$ \\
\hline Boys (7-18 years) & 3.6 & 1.4 & 2.9 & 3.9 & $3 \cdot 6$ & $3.5,3.7$ & $3 \cdot 1$ & $3 \cdot 1,3 \cdot 2$ & 3.5 & $3.5,3.6$ & 3.9 & $3 \cdot 9,4 \cdot 0$ \\
\hline Women (19-69 years) & 3.7 & 1.4 & $3 \cdot 0$ & 4.0 & $3 \cdot 7$ & $3 \cdot 6,3 \cdot 8$ & $3 \cdot 3$ & $3 \cdot 3,3 \cdot 4$ & $3 \cdot 6$ & $3 \cdot 6,3 \cdot 7$ & 4.0 & $3 \cdot 9,4 \cdot 1$ \\
\hline Men (19-69 years) & $4 \cdot 8$ & 1.8 & 3.9 & $5 \cdot 1$ & $4 \cdot 8$ & $4.7,4.9$ & $4 \cdot 3$ & $4 \cdot 2,4 \cdot 4$ & 4.7 & $4 \cdot 6,4 \cdot 8$ & $5 \cdot 2$ & $5 \cdot 0,5 \cdot 3$ \\
\hline
\end{tabular}

GHGE, greenhouse gas emissions; $\mathrm{CO}_{2} \mathrm{e}, \mathrm{CO}_{2}$-equivalents; $\mathrm{P}$, percentile.

†Used to define low (below or equal to P33), intermediate (P33-P66) and high (higher than P66) environmental load diets.

$\ddagger$ Correction for within-person variability and weighted for sociodemographic factors, season and day of the week.

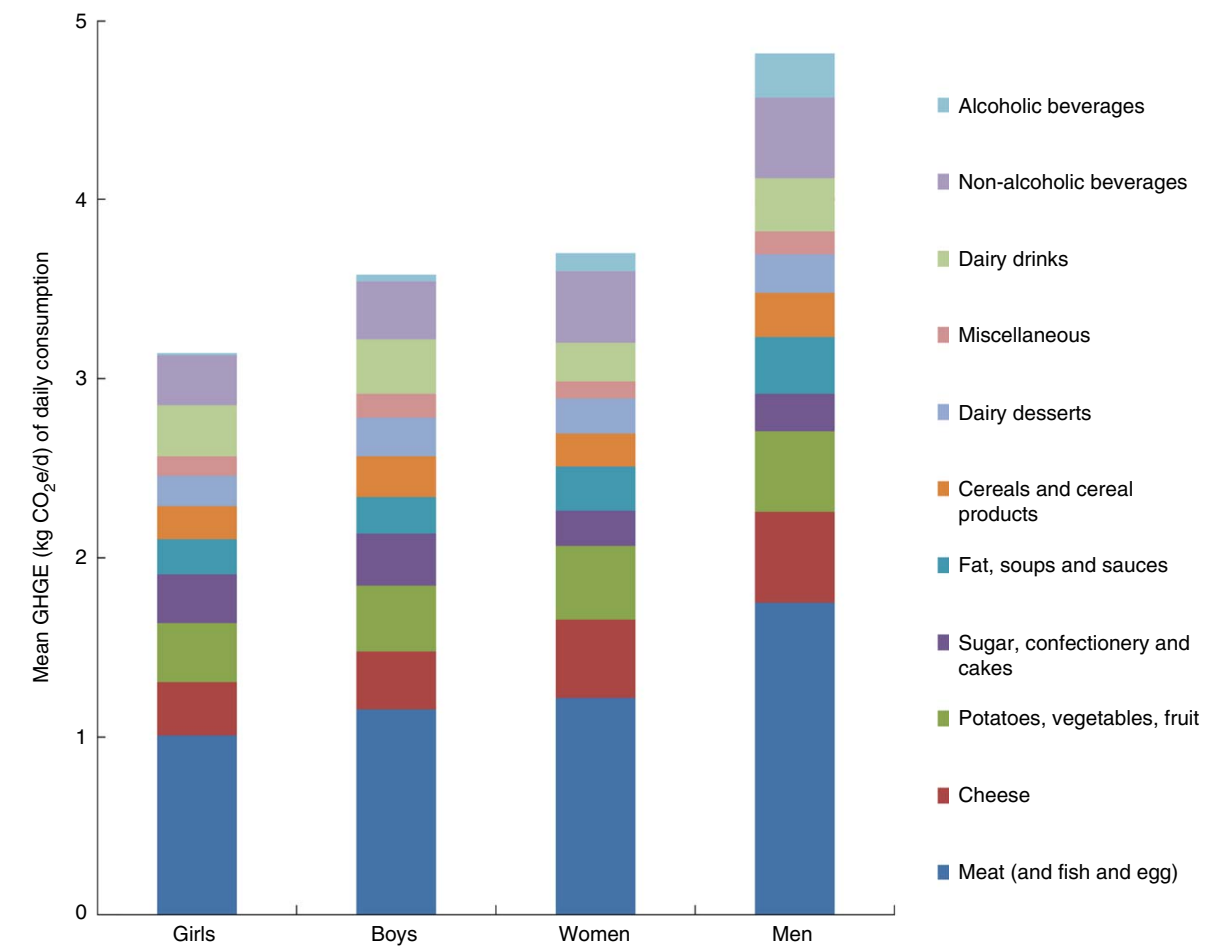

Fig. 2 (colour online) Mean greenhouse gas emissions (GHGE) for a day's consumption (in kg $\mathrm{CO}_{2}$-equivalents $\left(\mathrm{CO}_{2} \mathrm{e}\right) / \mathrm{d}$ ) for Dutch girls, women, boys and men, and major contributing sources

Girls, boys and women with diets of higher as compared with lower environmental load were not significantly more active as measured by the physical activity level (in MET $\times \mathrm{h} /$ week), but men were. Men with higherenvironmental-load diets were significantly more active $(P=0.0014)$ than men with low-environmental-load diets. BMI and BMR were higher $\left(+1.6 \mathrm{~kg} / \mathrm{m}^{2}\right.$ in girls and $+2.7 \mathrm{~kg} / \mathrm{m}^{2}$ in boys for BMI; $+0.6 \mathrm{MJ} / \mathrm{d}$ in girls and $+1.4 \mathrm{MJ} / \mathrm{d}$ in boys for BMR) in children with high- compared with low-environmental-load diets $(P<0 \cdot 001)$, after adjustments for differences in age. In adult women and men, BMI and BMR were similar within the different groups of diet environmental load.

\section{Total food and energy intakes}

The average total quantity of foods and drinks consumed was $2.2(\mathrm{sD} 0.6) \mathrm{kg} / \mathrm{d}, 2.5$ (sD 0.8$) \mathrm{kg} / \mathrm{d}, 3 \cdot 1$ (sD 0.9) kg/d and 3.4 (SD 1.0) $\mathrm{kg} / \mathrm{d}$ for girls, boys, women and men, respectively. Of this, $0 \cdot 9-1 \cdot 1 \mathrm{~kg} / \mathrm{d}$ was from foods and the remaining weight was from drinks.

Regarding within-group comparisons (see Tables 4 and 5), girls and women in the high environmental load group consumed about $0.5 \mathrm{~kg}$ ( $300 \mathrm{~g}$ of food and $200 \mathrm{~g}$ of drinks) more daily than their counterparts in the low environmental load group. Boys and men in the high environmental load group consumed about $1 \mathrm{~kg}$ (400-500 g of food and 500-600 g drinks) more daily than their counterparts in the low environmental load group. Total daily energy intake was higher in the high- $v$. the low-environmental-load diets: for girls and women this difference was approximately $2600 \mathrm{~kJ}$; for boys and men this difference was about $4400 \mathrm{~kJ}$ (about $+50 \%$ ). Higher GHGE of diets was associated with a higher EI:BMR in all groups. GHGE of diets was associated with EI:PAL in girls 
Table 2 Characteristics of Dutch girls and boys (7-18 years) with diets of low, intermediate and high environmental load based on habitual GHGE for a day's consumption

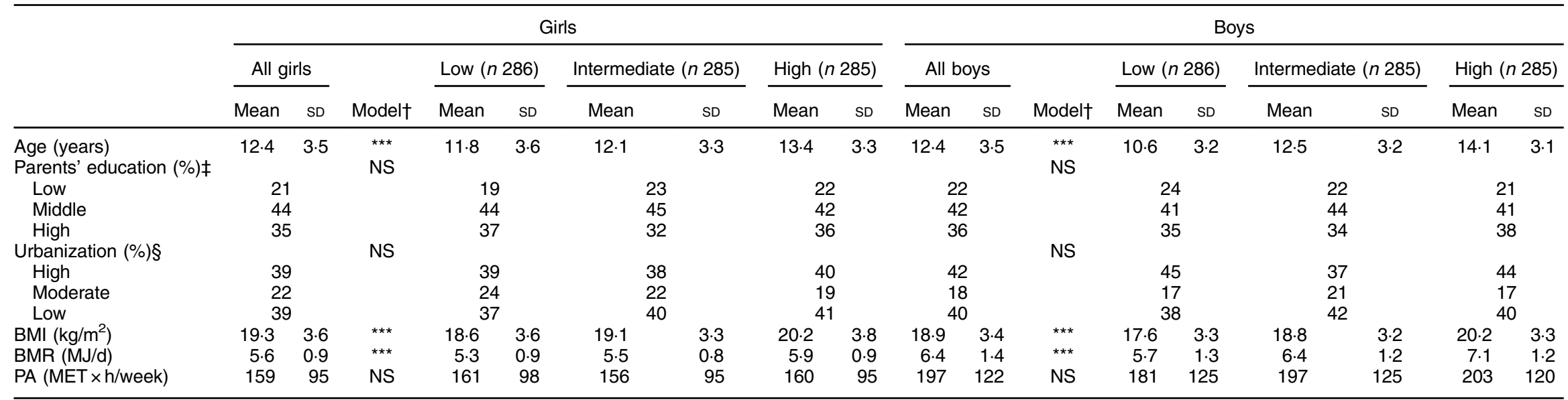

GHGE, greenhouse gas emissions; PA, physical activity; MET, metabolic equivalent of task.

${ }^{\star} P<0.05,{ }^{* *} P<0.01,{ }^{\star * *} P<0.001$

tModel to evaluate associations per age and gender group, model adjusted for age.

ҒEducation: low = primary education, lower vocational education and advanced elementary education; middle =intermediate vocational education and higher general secondary education; high =higher vocational education and university.

§Urbanization: high, $\geq 1500$ addresses $/ \mathrm{km}^{2}$; moderate, $1000-<1500$ addresses $/ \mathrm{km}^{2}$; low, $<1000$ addresses $/ \mathrm{km}^{2}$.

Table 3 Characteristics of Dutch women and men (>18 years) with diets of low, intermediate and high environmental load based on habitual GHGE for a day's consumption

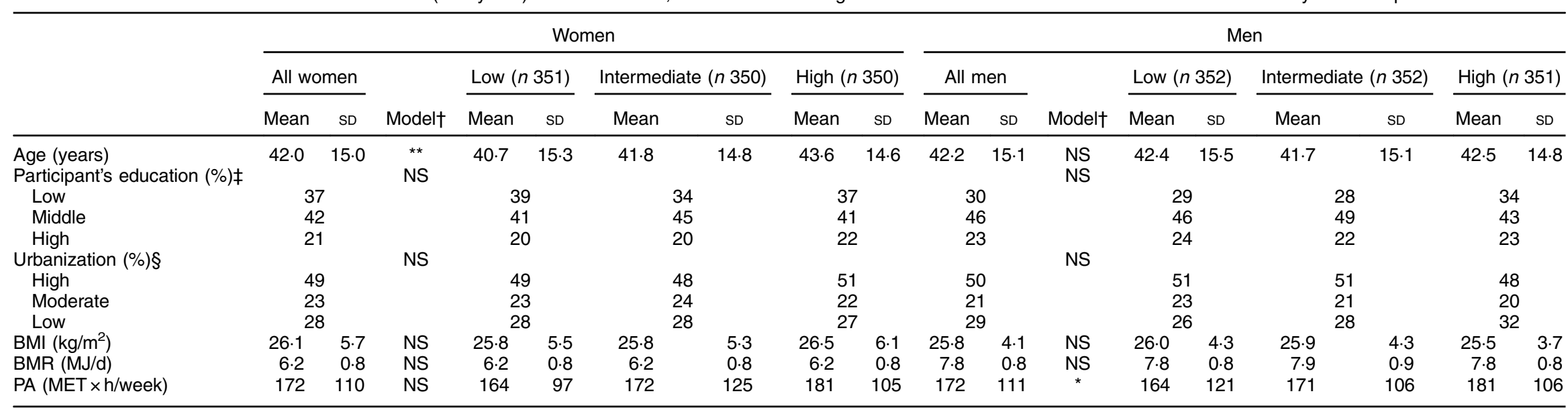

GHGE, greenhouse gas emissions; PA, physical activity; MET, metabolic equivalent of task.

${ }^{\star} P<0.05,{ }^{* \star} P<0.01,{ }^{* \star \star} P<0.001$.

tModel to evaluate associations per age and gender group, model adjusted for age.

fEducation: low = primary education, lower vocational education and advanced elementary education; middle =intermediate vocational education and higher general secondary education; high $=$ higher vocational

education and university.

§Urbanization: high, $\geq 1500$ addresses $/ \mathrm{km}^{2}$; moderate, $1000-<1500$ addresses $/ \mathrm{km}^{2}$; low, $<1000$ addresses $/ \mathrm{km}^{2}$. 
Table 4 Total food intake, El and ratios with BMR and PAL of Dutch girls and boys (7-18 years) with diets of low, intermediate and high environmental load based on habitual GHGE for a day's consumption

\begin{tabular}{|c|c|c|c|c|c|c|c|c|c|c|c|c|c|c|c|c|c|c|}
\hline & \multicolumn{9}{|c|}{ Girls } & \multicolumn{9}{|c|}{ Boys } \\
\hline & \multicolumn{2}{|c|}{ All girls } & \multirow[b]{2}{*}{ Model† } & \multicolumn{2}{|c|}{ Low (n 286) } & \multicolumn{2}{|c|}{ Intermediate ( $n$ 285) } & \multicolumn{2}{|c|}{ High (n 285) } & \multicolumn{2}{|c|}{ All boys } & \multirow[b]{2}{*}{ Model† } & \multicolumn{2}{|c|}{ Low (n 286) } & \multicolumn{2}{|c|}{ Intermediate $(n 285)$} & \multicolumn{2}{|c|}{ High (n 285) } \\
\hline & Mean & SD & & Mean & SD & Mean & SD & Mean & SD & Mean & SD & & Mean & SD & Mean & SD & Mean & SD \\
\hline Consumption ( $g / d)$ & 2222 & 601 & $\star \star \star \star ~$ & 1966 & 505 & 2180 & 490 & 2521 & 658 & 2467 & 775 & 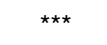 & 2004 & 468 & 2426 & 541 & 2972 & 908 \\
\hline Energy $(\mathrm{kJ} / \mathrm{d})$ & 8462 & 1888 & $\star \star \star \star ~$ & 7237 & 1473 & 8493 & 1455 & 9633 & 1921 & 10059 & 2952 & $* * *$ & 7922 & 1530 & 9917 & 1934 & 12365 & 3215 \\
\hline Energy (kcal/d) & 2015 & 451 & $* * *$ & 1728 & 344 & 2023 & 347 & 2295 & 459 & 2396 & 705 & $* * *$ & 1885 & 365 & 2362 & 461 & 2943 & 767 \\
\hline $\begin{array}{l}\text { Calculated ratios } \\
\text { Fl.BMR }\end{array}$ & & & & & & & & & & & & & & & & & & \\
\hline El:BMR & 1.55 & 0.39 & 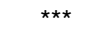 & 1.41 & 0.36 & 1.57 & 0.33 & 1.68 & 0.42 & 1.60 & 0.42 & 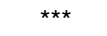 & 1.44 & 0.36 & 1.59 & 0.36 & 1.77 & 0.45 \\
\hline El:PAL $(\mathrm{kJ} / \mathrm{MET} \times \mathrm{h})$ & 579 & 638 & $* *$ & 465 & 501 & 581 & 476 & 656 & 799 & 652 & 1042 & NS & 721 & 1692 & 576 & 737 & 680 & 858 \\
\hline
\end{tabular}

El, energy intake; PAL, physical activity level; GHGE, greenhouse gas emissions; MET, metabolic equivalent of task

†Model to evaluate associations per age and gender group, model adjusted for age.

Table 5 Total food intake, El and ratios with BMR and PAL of Dutch women and men (>18 years) with diets of low, intermediate and high environmental load based on habitual GHGE for a day's consumption

\begin{tabular}{|c|c|c|c|c|c|c|c|c|c|c|c|c|c|c|c|c|c|c|}
\hline & \multicolumn{9}{|c|}{ Women } & \multicolumn{9}{|c|}{ Men } \\
\hline & \multicolumn{2}{|c|}{ All women } & \multirow[b]{2}{*}{ Model† } & \multicolumn{2}{|c|}{ Low (n 351) } & \multicolumn{2}{|c|}{ Intermediate ( $n$ 350) } & \multicolumn{2}{|c|}{ High (n 350) } & \multicolumn{2}{|c|}{ All men } & \multirow[b]{2}{*}{ Model† } & \multicolumn{2}{|c|}{ Low ( $n$ 352) } & \multicolumn{2}{|c|}{ Intermediate ( $n$ 352) } & \multicolumn{2}{|c|}{ High (n 351) } \\
\hline & Mean & SD & & Mean & SD & Mean & SD & Mean & SD & Mean & SD & & Mean & SD & Mean & SD & Mean & SD \\
\hline Consumption (g/d) & 3134 & 862 & *** & 2845 & 823 & 3139 & 825 & 3420 & 842 & 3408 & 956 & *** & 2913 & 707 & 3389 & 770 & 3923 & 1069 \\
\hline Energy $(\mathrm{kJ} / \mathrm{d})$ & 8209 & 2301 & $\star * \star *$ & 6711 & 1716 & 8245 & 1772 & 9607 & 2374 & 11023 & 3165 & 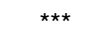 & 8757 & 2158 & 11215 & 2401 & 13082 & 3228 \\
\hline $\begin{array}{l}\text { Energy }(\mathrm{kcal} / \mathrm{d}) \\
\text { Calculated ratios }\end{array}$ & 1957 & 550 & $\star \star \star *$ & 1609 & 409 & 1965 & 423 & 2299 & 570 & 2630 & 756 & $* * *$ & 2095 & 512 & 2676 & 573 & 3120 & 775 \\
\hline El:BMR & 1.34 & 0.41 & $\star * \star *$ & $1 \cdot 11$ & 0.32 & 1.34 & 0.32 & 1.57 & 0.44 & 1.43 & 0.43 & 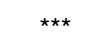 & $1 \cdot 14$ & 0.30 & 1.44 & 0.35 & 1.69 & 0.43 \\
\hline El:PAL $(\mathrm{kJ} / \mathrm{MET} \times \mathrm{h})$ & 496 & 529 & $\star *$ & 441 & 522 & 510 & 533 & 539 & 529 & 741 & 1202 & NS & 676 & 963 & 736 & 920 & 811 & 1601 \\
\hline
\end{tabular}

El, energy intake; PAL, physical activity level; GHGE, greenhouse gas emissions; MET, metabolic equivalent of task.

†Model to evaluate associations per age and gender group, model adjusted for age. 


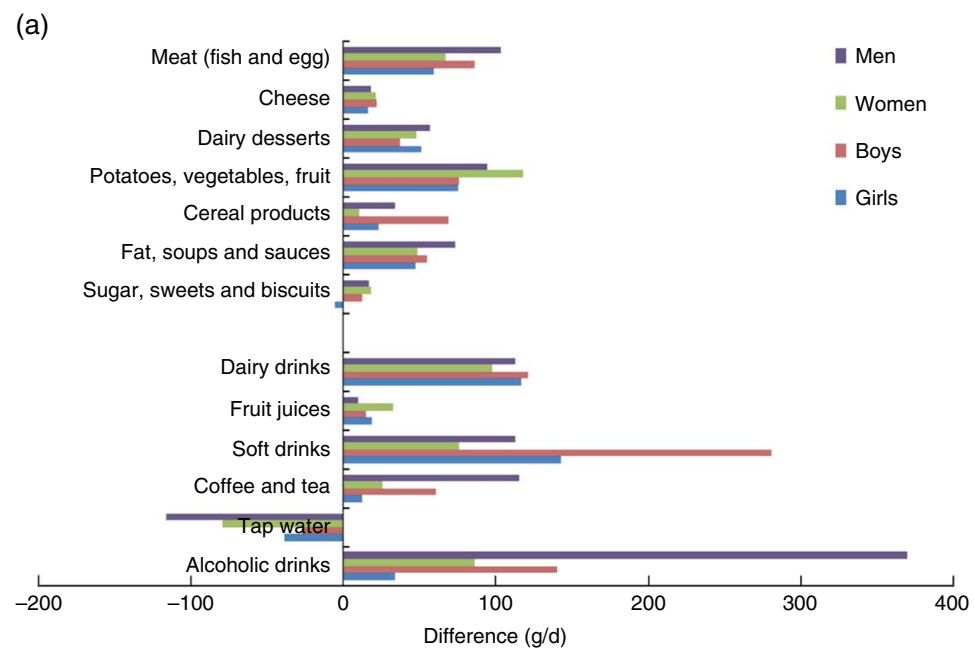

(b)

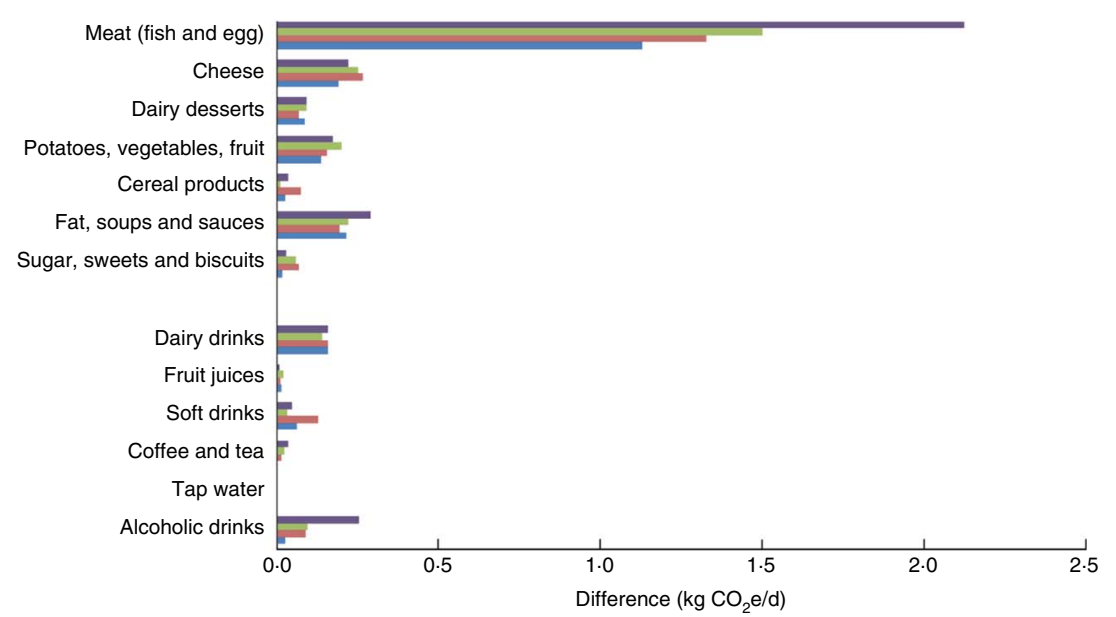

Fig. 3 (colour online) Differences in (a) consumed quantities (in $\mathrm{g} / \mathrm{d}$ or $\mathrm{ml} / \mathrm{d}$ ) and (b) greenhouse gas emissions (GHGE) of consumed diets (in $\mathrm{kg} \mathrm{CO}$-equivalents $\left(\mathrm{CO}_{2} \mathrm{e}\right) / \mathrm{d}$ ) within groups of Dutch girls, boys, women and men, when comparing diets with a high and a low environmental load

and women; for boys and men the association was not significant.

\section{Types of foods and drinks}

Figure 3(a) depicts the types of food and drinks (calculated from the two dietary recall days) consumed, comparing the high with the low dietary environmental load group. Higher intakes were from all types of foods; from animal-based food groups (meat, dairy, fish and egg) and plant-based food groups (potatoes, vegetables, legumes, fruits, cereal products), as well as drinks. The average intake of meat (and fish and eggs) was $70 \mathrm{~g} / \mathrm{d}, 77 \mathrm{~g} / \mathrm{d}, 84 \mathrm{~g} / \mathrm{d}$ and $117 \mathrm{~g} / \mathrm{d}$, respectively, in girls, boys, women and men in the low GHGE group and was almost twice as high in the high GHGE group. Men in the high environmental load group consumed $220 \mathrm{~g} / \mathrm{d}$ and a larger share was from beef. Cheese consumption was almost twice as high comparing the high with the low environmental load group. Dairy drink and dessert consumption was about $60 \%$ higher in the high environmental load compared with the low environmental load group. Consumption of potatoes, vegetables and fruits was $30-40 \%$ higher in the high compared with the low environmental load group.

Notable differences existed in the drinks category. Within all groups, consumption of dairy drinks was higher (about $+110 \mathrm{~g} / \mathrm{d}$ ) in the high compared with the low environmental load group. Boys in the high compared with the low environmental load group drank more soft drinks $(+281 \mathrm{ml} / \mathrm{d})$. Men in the high GHGE group drank more alcoholic drinks $(+370 \mathrm{ml} / \mathrm{d})$, coffee and tea, and soft drinks (combined $+100 \mathrm{ml} / \mathrm{d}$ ) than those in the low GHGE group. Tap water consumption was, in all groups, lower in the high environmental load group compared with the low environmental load group.

Differences in the consumption of animal foods (especially (type of) meat; on average $+79 \mathrm{~g} / \mathrm{d}$ more in the high than in the low environmental load group) determined most of the differences in environmental load of the participants' diets (see Fig. 3(b)). Differences in soft drink consumption did not translate into a large difference in 
Table 6 Daily intakes of fibre and macronutrients of Dutch girls and boys (7-18 years) with diets of low, intermediate and high environmental load based on habitual GHGE for a day's consumption

\begin{tabular}{|c|c|c|c|c|c|c|c|c|c|c|c|c|c|c|c|c|c|c|}
\hline & \multicolumn{9}{|c|}{ Girls } & \multicolumn{9}{|c|}{ Boys } \\
\hline & \multicolumn{2}{|c|}{ All girls } & \multirow[b]{2}{*}{ Model† } & \multicolumn{2}{|c|}{ Low $(n$ 286) } & \multicolumn{2}{|c|}{ Intermediate $(n$ 285) } & \multicolumn{2}{|c|}{ High (n 285) } & \multicolumn{2}{|c|}{ All boys } & \multirow[b]{2}{*}{ Model $\dagger$} & \multicolumn{2}{|c|}{ Low $(n$ 286) } & \multicolumn{2}{|c|}{ Intermediate ( $n$ 285) } & \multicolumn{2}{|c|}{ High ( $n$ 285) } \\
\hline & Mean & SD & & Mean & SD & Mean & SD & Mean & SD & Mean & SD & & Mean & SD & Mean & SD & Mean & SD \\
\hline Fibre (g/MJ) & $2 \cdot 0$ & 0.5 & 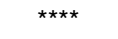 & $2 \cdot 1$ & 0.6 & $2 \cdot 0$ & 0.5 & 1.9 & 0.5 & 1.9 & 0.5 & 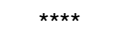 & 2 & 0.5 & 1.9 & 0.5 & 1.8 & 0.5 \\
\hline Fat $(E \%)$ & 34 & 6 & $\star * \star \star *$ & 32 & 6 & 34 & 6 & 35 & 6 & 33 & 6 & 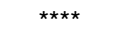 & 31 & 6 & 34 & 6 & 35 & 6 \\
\hline of which SFA & 13 & 3 & 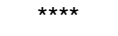 & 12 & 3 & 13 & 2 & 14 & 3 & 12 & 3 & 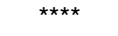 & 11 & 3 & 13 & 3 & 13 & 3 \\
\hline Protein (E\%) & 13 & 3 & $\star * \star *$ & 13 & 3 & 13 & 3 & 14 & 3 & 13 & 3 & 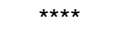 & 12 & 3 & 13 & 3 & 14 & 3 \\
\hline of which vegetable protein & 5 & 1 & $\star * \star * *$ & 6 & 1 & 5 & 1 & 5 & 1 & 5 & 1 & $\star \star \star \star *$ & 5 & 1 & 5 & 1 & 5 & 1 \\
\hline of which animal protein & 8 & 3 & $\star \star * \star *$ & 7 & 3 & 8 & 3 & 9 & 3 & 8 & 3 & $* * \star *$ & 7 & 3 & 8 & 2 & 9 & 3 \\
\hline Carbohydrates (E\%) & 51 & 6 & 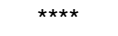 & 53 & 6 & 51 & 6 & 49 & 6 & 51 & 7 & $\star \star \star \star *$ & 54 & 6 & 51 & 6 & 48 & 6 \\
\hline of which mono- and disaccharides & 27 & 7 & $\star \star \star \star *$ & 28 & 7 & 27 & 7 & 26 & 7 & 27 & 7 & 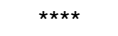 & 29 & 7 & 26 & 6 & 25 & 7 \\
\hline of which polysaccharides & 24 & 5 & **** & 26 & 5 & 24 & 4 & 23 & 4 & 25 & 4 & $* \star \star \star *$ & 25 & 5 & 25 & 4 & 24 & 4 \\
\hline Alcohol (E\%) & 0 & 2 & $\star \star \star \star ~$ & 0 & 2 & 0 & 1 & 1 & 3 & 0 & 2 & 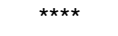 & 0 & 1 & 0 & 1 & 1 & 4 \\
\hline
\end{tabular}

GHGE, greenhouse gas emissions; E\%, percentage of energy.

tModel to evaluate associations per age and gender group, model adjusted for age.

Table 7 Daily intakes of fibre and macronutrients of Dutch women and men (>18 years) with diets of low, intermediate and high environmental load based on habitual GHGE for a day's consumption

\begin{tabular}{|c|c|c|c|c|c|c|c|c|c|c|c|c|c|c|c|c|c|c|}
\hline & \multicolumn{9}{|c|}{ Women } & \multicolumn{9}{|c|}{ Men } \\
\hline & \multicolumn{2}{|c|}{ All women } & \multirow[b]{2}{*}{ Model† } & \multicolumn{2}{|c|}{ Low $(n 351)$} & \multicolumn{2}{|c|}{ Intermediate ( $n$ 350) } & \multicolumn{2}{|c|}{ High (n 350) } & \multicolumn{2}{|c|}{ All men } & \multirow[b]{2}{*}{ Model† } & \multicolumn{2}{|c|}{ Low $(n$ 352) } & \multicolumn{2}{|c|}{ Intermediate $(n$ 352) } & \multicolumn{2}{|c|}{ High ( $n$ 351) } \\
\hline & Mean & SD & & Mean & SD & Mean & SD & Mean & SD & Mean & SD & & Mean & SD & Mean & SD & Mean & SD \\
\hline Fibre (g/MJ) & $2 \cdot 3$ & 0.7 & 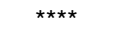 & 2.5 & 0.8 & $2 \cdot 3$ & $0 \cdot 7$ & $2 \cdot 2$ & 0.7 & $2 \cdot 1$ & $0 \cdot 6$ & **** & $2 \cdot 2$ & $0 \cdot 7$ & $2 \cdot 1$ & 0.6 & $2 \cdot 0$ & 0.6 \\
\hline Fat $(E \%)$ & 34 & 7 & 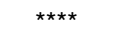 & 33 & 7 & 34 & 7 & 36 & 6 & 35 & 6 & $* \star \star$ & 34 & 7 & 35 & 6 & 35 & 6 \\
\hline of which SFA & 13 & 3 & 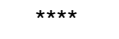 & 12 & 3 & 13 & 3 & 14 & 3 & 13 & 3 & **** & 12 & 3 & 13 & 3 & 13 & 3 \\
\hline Protein & 16 & 4 & 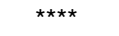 & 15 & 4 & 15 & 3 & 16 & 4 & 15 & 3 & **** & 15 & 4 & 15 & 3 & 16 & 3 \\
\hline of which vegetable protein & 6 & 1 & $\star \star \star \star *$ & 6 & 2 & 6 & 1 & 5 & 1 & 6 & 1 & $\star \star \star \star *$ & 6 & 4 & 6 & 1 & 5 & 1 \\
\hline of which animal protein & 10 & 4 & 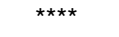 & 9 & 4 & 9 & 3 & 11 & 4 & 10 & 3 & 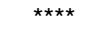 & 9 & 4 & 9 & 3 & 11 & 3 \\
\hline Carbohydrates (E\%) & 45 & 8 & 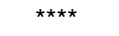 & 47 & 8 & 46 & 7 & 42 & 8 & 43 & 7 & 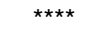 & 45 & 8 & 43 & 7 & 41 & 7 \\
\hline of which mono- and disaccharides & 21 & 7 & *** & 22 & 7 & 22 & 7 & 20 & 7 & 19 & 7 & $\star \star \star \star *$ & 20 & 8 & 19 & 7 & 18 & 7 \\
\hline of which polysaccharides & 24 & 5 & $\star \star * \star *$ & 26 & 6 & 24 & 5 & 22 & 5 & 24 & 5 & $\star \star * * *$ & 25 & 6 & 24 & 5 & 23 & 4 \\
\hline Alcohol (E\%) & 3 & 5 & 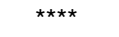 & 2 & 4 & 3 & 5 & 4 & 5 & 5 & 6 & **** & 4 & 6 & 5 & 6 & 6 & 7 \\
\hline
\end{tabular}

GHGE, greenhouse gas emissions; E\%, percentage of energy.

tModel to evaluate associations per age and gender group, model adjusted for age. 


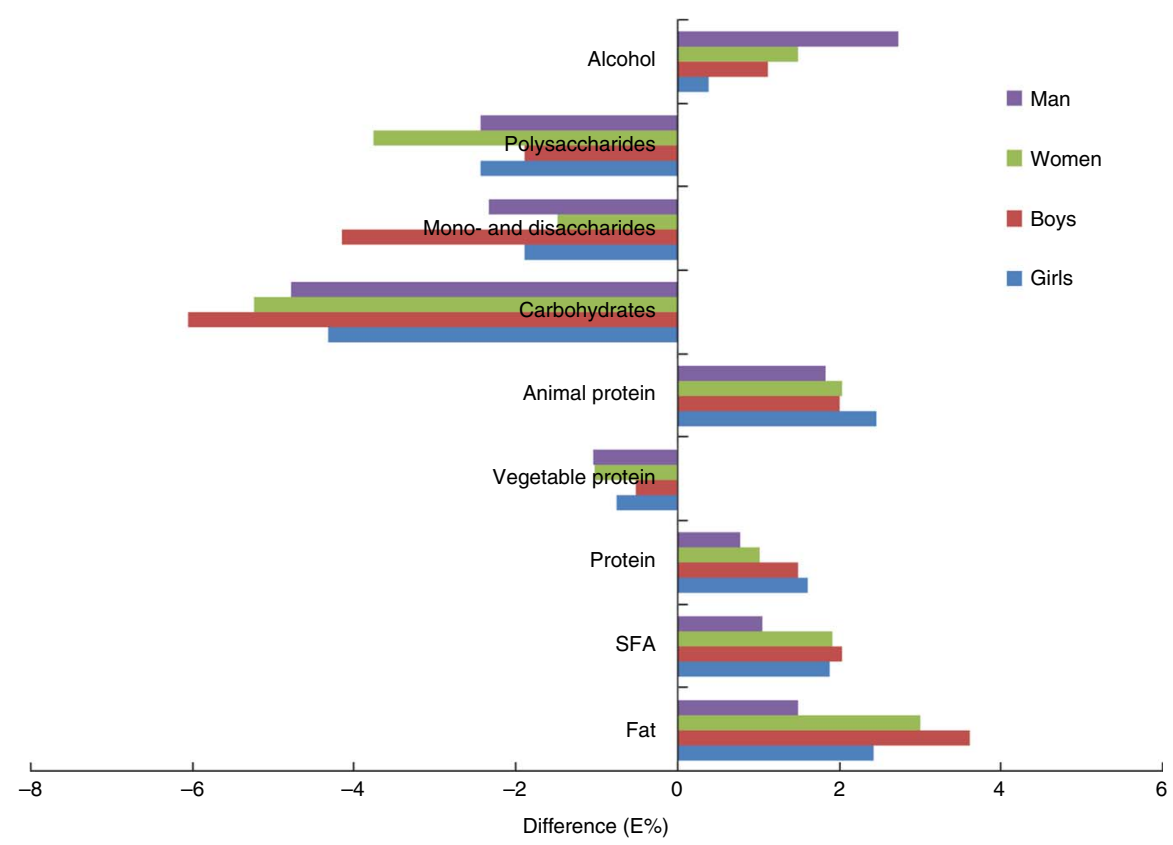

Fig. 4 (colour online) Differences in macronutrient intakes (in percentage of total energy intake (E\%)) within groups of Dutch girls, boys, women and men, when comparing diets with a high and a low environmental load

environmental load; differences in alcoholic drinks did to a certain extent, particularly in men.

\section{Macronutrient intakes}

Tables 6 and 7 show the average daily intakes of fibre (per MJ) and macronutrients (as a percentage of total energy intake (E\%)) per tertile of dietary GHGE. Figure 4 shows the differences within groups with diets of high as compared with low environmental load. Intakes of total fat, saturated fat, animal-based protein and alcohol were significantly higher, by $2-3 \mathrm{E} \%$, in the high- compared with the low-environmental-load diets. On the other hand, the contribution of vegetable protein ( $-1 \mathrm{E} \%)$ and carbohydrate (mono- and disaccharides as well as polysaccharides) to total energy intake was $-4 \mathrm{E} \%$. In addition, fibre intake was lower in the high compared with the low environmental load group (Tables 6 and 7).

\section{Discussion}

The present study evaluated the GHGE of diets in Dutch girls, women, boys and men separately and evaluated high- compared with low-environmental-load diets for differences in diet composition, total (food and energy) intake and macronutrient intakes. Meat and cheese contributed about $40 \%$ and drinks (including milk and alcoholic drinks) $20 \%$ to daily GHGE. This was similar in all age and gender groups. Considerable variation in environmental loads of diets existed within age and gender groups. Major differences between high- and lowGHGE diets were in meat, cheese and dairy consumption as well as in soft drinks (girls, boys and women) and alcoholic drinks (men). Of those, differences in (type of) meat consumption determined the differences in GHGE most. The significant association between GHGE of diets and EI:PAL in women suggested that energy intakes are balanced less with the level of physical activity in females with high-environmental-load compared with low-environmental-load diets. Independent of the total amount of energy, the high-environmental-load diets contain significantly more (saturated) fat, more animal protein and more alcohol (especially in men) and less vegetable protein, carbohydrates and fibre.

Recent studies have analysed GHGE of modelled diets ${ }^{(20)}$ or observed diets ${ }^{(12,21)}$ and compared these with calculated nutritional intakes ${ }^{(20)}$ as well as with a combined diet score $^{(21)}$. In a recent study by Vieux et $a l .{ }^{(21)}$, higher dietrelated GHGE was associated with higher fruit and vegetables as well as higher meat and fish consumption. Similarly, we found that higher GHGE of daily diets was associated with higher intakes of plant-based foods and even higher intakes of animal foods (see Fig. 3). In agreement with more animal foods in the diets, the high-GHGE diets contained more (saturated) fat, more animal protein, more alcohol, and less vegetable protein and carbohydrates. Vieux et $a l^{(21)}$ by correcting for energy intake beforehand and available modelling studies ${ }^{(15,20,21,28)}$ did not take into account the different levels of energy intake that are observed at the population level, especially in relation to physical activity levels. In a previous study however, Vieux and colleagues showed that when energy intakes were reduced to meet individual energy needs the diet-associated GHGE may be reduced up to $10 \%{ }^{(12)}$. Efforts to balance energy intakes with energy requirements are the most 
efficient and feasible via animal-based foods and via sugarand alcohol-containing drinks, especially in highenvironmental-impact diets. For example, $418 \mathrm{~kJ}$ (100 kcal) is represented by $37 \mathrm{~g}$ of pig meat, $27 \mathrm{~g}$ of cheese, $161 \mathrm{~g}$ of apple, $370 \mathrm{~g}$ of broccoli, $243 \mathrm{~g}$ of sugar-containing beverage or $217 \mathrm{~g}$ of beer. Lower intake of animal foods will also decrease GHGE by $0.3 \mathrm{~kg} \mathrm{CO} 2 \mathrm{e}$ (for $37 \mathrm{~g}$ lower intake of pig meat or $27 \mathrm{~g}$ less cheese). Not drinking or replacing sugaror alcohol-containing drinks by tap water will decrease GHGE by on average $0.3 \mathrm{~kg} \mathrm{CO}_{2} \mathrm{e}$ for children and up to $0.7 \mathrm{~kg} \mathrm{CO} 2 \mathrm{e}$ for men. In most dietary guidelines around the world, balancing energy intake with requirement is the most prominent message given ${ }^{(29)}$. An unfavourable dietary composition additionally leads to considerable health loss, especially via the high intakes of saturated and trans fatty acids and low intakes of fish, fruit and vegetables ${ }^{(30)}$. However, consumption of meat, cheese, sugar- and alcoholcontaining drinks is rooted in the current Dutch eating culture. Lowering their consumption, therefore, will not be easy and has implications for other determinants such as taste, cultural acceptability, the position of foods in meals and price, as well as nutritional consequences.

It is a challenge to identify diets with less environmental impact without compromising the nutritional quality of the diet, especially in risk groups for inadequate intakes in the Netherlands. In currently observed diets in the Netherlands, meat products contribute more than $15 \%$ to intakes of $\mathrm{Fe}, \mathrm{P}, \mathrm{Se}, \mathrm{Zn}$, retinol, thiamin and vitamins $\mathrm{B}_{6}, \mathrm{~B}_{12}$ and $\mathrm{D}$, as well as EPA and DHA ${ }^{(22)}$. Dairy products contribute more than $15 \%$ to intakes of $\mathrm{Ca}, \mathrm{Mg}, \mathrm{P}, \mathrm{K}, \mathrm{Zn}$, retinol, riboflavin and vitamin $\mathrm{B}_{12}{ }^{(22)}$. On the other hand, meat and dairy products contribute to unfavourably high intakes of SFA and trans-fatty acids. Average SFA intake currently exceeds the recommended maximum of $10 \mathrm{E} \%{ }^{(22)}$. This is similar in other European countries ${ }^{(31)}$. A recent European evaluation suggests low intakes of minerals and vitamin D in specific age groups ${ }^{(32)}$. So, probably a more targeted group and/or even an individual approach is needed to advise how a more environmentally friendly and healthy food consumption can be reached. Such advice should start with energy intakes $v$. requirements and take into account the environmental load as well as the nutrient composition of currently consumed foods and possible replacement foods. In a previous modelling study, we showed ${ }^{(33)}$ that with carefully chosen currently available replacement foods it is possible to lower the environmental load of diets while maintaining current total Fe levels and reducing SFA levels for young Dutch females (19-30 years). However, other nutrients were not assessed ${ }^{(33)}$. Further research on the effects of replacement or reduction scenarios on vitamin and mineral intakes is needed. Identifying ranges including upper levels of recommended intakes of meat, cheese and dairy may help consumers towards diets with lower GHGE.

Studies in the field of sustainable diets ${ }^{(20,21,28)}$ as well as food-based dietary guidelines focus mainly on solid foods.
Yet, our study shows that one-fifth of the daily load is attributable to drinks. While the load per kilogram is relatively low, consumption is high and large differences in consumed amounts exist within age and gender groups. On average, non-alcoholic drinks contributed $17 \%$ to daily GHGE and alcoholic drinks another 3\% in women and $5 \%$ in men. Dutch children drank more soft drinks (girls $+143 \mathrm{~g} / \mathrm{d}$ and boys $+280 \mathrm{~g} / \mathrm{d}$ ) and men more alcoholic drinks $(+370 \mathrm{~g} / \mathrm{d})$, but less tap water, in the high- compared with the low-environmental-load diet. Drinking less sugar- and alcohol-containing drinks would reduce both the GHGE of daily diets as well as energy intake. Previous studies showed that the consumption of sugar-containing beverages is associated with overweight in a longitudinal trial $^{(34)}$ as well as with higher body weight in a randomized trial $^{(35)}$. Our cross-sectional analyses indicated about $2 \mathrm{~kg} / \mathrm{m}^{2}$ higher BMI in children with diets with high compared with low environmental loads. On the other hand, GHGE of diets was not associated with physical activity levels in girls and weakly associated in boys.

The strength of the present study is the new type of research question that combines the disciplines of environmental impact assessment and public health nutrition. For the first time, the diets of children have been analysed for environmental loads. The study identifies associations of food as well as drink consumption with environmental load and identifies opportunities to reduce the environmental load, starting from observed consumption patterns. In the current paper, we relied on the environmental indicator GHGE as a proxy for environmental impact. While this indicator is generally in line with other indicators such as land use and use of fossil energy, emissions may not always indicate an absence of other environmental impacts. For example, while a certain crop such as tomatoes produced in Spain may not be GHGE intensive, the reliance on irrigation may exacerbate water stress in countries that experience water scarcity ${ }^{(36)}$.

Understanding the quality of data underlying these analyses as well as the uncertainties involved is of major importance. Data on GHGE may vary because of farming methods, animal feed, use of side products, transport and growing conditions ${ }^{(1)}$. In our case, we have tried to be as representative as possible for the Dutch situation by taking into account all steps between primary production and preparation by the consumer, and by including waste treatment. In most cases, the GHGE estimates of foods are determined largely by the primary production phase. For the impacts of drinks, the share of packaging was more important and for brewed coffee and tea the boiling of water was the most dominant part. GHGE estimations were available for the most frequently consumed foods. Extrapolations were made for all other foods consumed except for spices, herbs and meal replacers. The uncertainty in the environmental indicators is due to known uncertainties in shares and amounts of fertilizers and variability in the energy inputs during processing steps. A similar method 
was used in a previous publication ${ }^{(21)}$, although sometimes based on fewer data and without including the retail and consumer phases and waste treatment ${ }^{(3)}$.

In addition, quality aspects of the food consumption survey and its food composition data are of importance for the interpretation of the study results. The average response rate in the food consumption survey was high (69\%). It was concluded that the study population adequately represented the Dutch population as a whole and was representative with regard to age and sex within each age group, region, degree of urbanization and education ${ }^{(22)}$. This means that results may be generalized to the Dutch population. In the dietary assessment, however, there may have been a tendency for under-reporting ${ }^{(22,37)}$. Calculations of EI:BMR confirmed this suggestion, especially for adults. On average, energy intake was underestimated by about $15 \%{ }^{(22)}$. It is therefore likely that GHGE was underestimated in a similar order of magnitude. The results comparing high and low GHGE groups must be interpreted with caution, especially in adults, since more under-reporting occurred in the low GHGE group. However, the energy percentage of animal protein and saturated fat were still lower in the low GHGE group compared with the high GHGE group, indicating that dietary differences between GHGE groups cannot be entirely explained by under-reporting. Moreover, some calculations were based on averages from the two recall days. Compared with calculations using corrections for within-person variability, the distribution based on two recall days was somewhat skewed with a left tail. This shows that GHGE in the lowest tertile was an underestimation of habitual GHGE of the diet. The calculations based on two recalls may also have resulted in some misclassification of participants with regard to their usual diet. For associations with personal characteristics this is expected to lead to attenuated relationships. For associations with dietary characteristics, associations within a daily menu might have partly driven the results. For the measures of physical activity levels, it should be realized that MET scores were based on questionnaires and were not the focus of the food consumption survey. We do not think that the above limitations lead to major flaws in the results. Caution, however, is needed when results are extrapolated to other populations.

The findings in the present paper may provide input for future food-based dietary guidelines as well as intervention strategies to lower the environmental load of diets of Dutch girls, boys, women and men. The GHGE of daily diets is on average $3.2 \mathrm{~kg} \mathrm{CO} 2 \mathrm{e}$ for girls, $3.6 \mathrm{~kg} \mathrm{CO} \mathrm{CO}_{2} \mathrm{e}$ for boys, $3.7 \mathrm{~kg} \mathrm{CO} 2 \mathrm{e}$ for women and $4.8 \mathrm{~kg} \mathrm{CO}_{2} \mathrm{e}$ for men in the Netherlands. Meat, cheese and drinks contribute more than half of daily GHGE. Considerable differences in environmental loads of diets exist within age and gender groups. A lower intake of animal-based foods (especially meat and cheese) and/or replacement by plant-based foods is associated with a reduced environmental load, as well as a lower SFA intake and a higher fibre intake, in children and adults. Reduced consumption and/or replacement of sugarand/or alcohol-containing drinks may additionally lower environmental impact as well as energy intake.

\section{Acknowledgements}

Acknowledgements: The authors thank Marja Beukers for performing the calculations of habitual environmental impact of diets. Financial support: The present study was funded by the Ministry of Economic Affairs. The Ministry of Economic Affairs had no role in the design, analysis or writing of this article. Conflict of interest: None. Authorship: E.H.M.T. initiated the study. E.H.M.T., I.B.T., G.F.H. K., M.C.C.B. and J.M.M.D. were involved in data collection and data analysis. M.C.C.B., E.H.M.T. and I.B.T. prepared the first draft of the manuscript, which was critically evaluated and refined by G.F.H.K., J.M.M.D., M.T. and M.C.O. E.H.M.T. prepared the final draft of the manuscript. All authors participated intellectually in the development of the paper. Ethics of buman subject participation: Ethical approval was not required.

\section{References}

1. Garnett T (2008) Cooking Up a Storm. Food, Greenbouse Gas Emissions and Our Changing Climate. Guildford: Food Climate Research Network, Centre for Environmental Strategy, University of Surrey.

2. Lang T \& Barling D (2013) Nutrition and sustainability: an emerging food policy discourse. Proc Nutr Soc 72, 1-12.

3. Macdiarmid JI (2013) Is a healthy diet an environmentally sustainable diet? Proc Nutr Soc 72, 13-20.

4. McMichael AJ, Powles JW, Butler CD et al. (2007) Food, livestock production, energy, climate change, and health. Lancet 370, 1253-1263.

5. Tukker A, Goldbohm RA, Koning dA et al. (2011) Environmental impacts of changes to healthier diets in Europe. Ecol Econ 70, 1776-1788.

6. Garnett T (2013) Food sustainability: problems, perspectives and solutions. Proc Nutr Soc 72, 29-39.

7. Macdiarmid J, Kyle J, Horgan G et al. (2011) Livewell: A Balance of Healthy and Sustainable Food Choices. Godalming: WWF-UK and Rowett Institute of Nutrition and Health.

8. Food and Agriculture Organization of the United Nations (2010) Definition of Sustainable Diets. Report of the International Scientific Symposium: Biodiversity and Sustainable Diets United Against Hunger, Rome, 3-5 November 2010. Rome: FAO.

9. Health Council of the Netherlands (2011) Guidelines for a Healthy Diet: The Ecological Perspective. The Hague: Health Council of the Netherlands.

10. Fisher K, James K, Sheane $\mathrm{R}$ et al. (2013) An Initial Assessment of the Environmental Impact of Grocery Products. Banbury: Product Sustainability Forum.

11. Solomon S, Qin D, Manning M et al. (editors) (2007) Climate Change 2007: The Physical Science Basis. Contribution of Working Group I to the Fourth Assessment Report of the Intergovernmental Panel on Climate Change. Cambridge: Cambridge University Press.

12. Vieux F, Darmon N, Touazi D et al. (2012) Greenhouse gas emissions of self-selected individual diets in France: changing the diet structure or consuming less? Ecol Econ 75, 91-101. 
13. Baroni L, Cenci L, Tettamanti M et al. (2007) Evaluating the environmental impact of various dietary patterns combined with different food production systems. Eur J Clin Nutr $\mathbf{6 1}$, 279-286.

14. Carlsson-Kanyama A \& Gonzalez AD (2009) Potential contributions of food consumption patterns to climate change. Am J Clin Nutr 89, issue 5, 1704S-1709S.

15. Marinussen M, Kramer G, Pluimers J et al. (2012) De milieudruk van ons eten. Een analyse op basis van de voedselconsumptiepeiling 2007-2010. Gouda: Blonk Milieu Advies.

16. Westhoek H, Rood T, van de Berg M et al. (2011) The Protein Puzzle. The Hague: PBL Netherlands Environmental Agency.

17. van Dooren C, Marinussen M, Blonk H et al. (2014) Exploring dietary guidelines based on ecological and nutritional values: a comparison of six dietary patterns. Food Policy 44, 36-46.

18. Berners-Lee M, Hoolohan C, Cammack H et al. (2012) The relative greenhouse gas impacts of realistic dietary choices. Energ Policy 43, 184-190.

19. Hoolohan C, Berners-Lee M, McKinstry-West J et al. (2013) Mitigating the greenhouse gas emissions embodied in food through realistic consumer choices. Energ Policy 63 , 1065-1074.

20. Macdiarmid JI, Kyle J, Horgan GW et al. (2012) Sustainable diets for the future: can we contribute to reducing greenhouse gas emissions by eating a healthy diet? Am J Clin Nutr 96, 632-639

21. Vieux F, Soler LG, Touazi D et al. (2013) High nutritional quality is not associated with low greenhouse gas emissions in self-selected diets of French adults. Am J Clin Nutr 97, 569-583.

22. Van Rossum CTM, Fransen HP, Verkaik-Kloosterman J et al. (2011) Dutch National Food Consumption Survey 2007-2010. Diet of Children and Adults Aged 7 to 69 Years. Bilthoven: RIVM.

23. Wendel-Vos GC, Schuit AJ, Saris WH et al. (2003) Reproducibility and relative validity of the short questionnaire to assess health-enhancing physical activity. J Clin Epidemiol 56, 1163-1169.

24. Schofield WN (1985) Predicting basal metabolic rate, new standards and review of previous work. Hum Nutr Clin Nutr 39, Suppl. 1, 5-41.

25. Slimani N, Ferrari P, Ocke M et al. (2000) Standardization of the 24-hour diet recall calibration method used in the European Prospective Investigation into Cancer and Nutrition
(EPIC): general concepts and preliminary results. Eur J Clin Nutr 54, 900-917.

26. NEVO (2011) NEVO online versie 2011/3.O. Bilthoven: RIVM; available at http://nevo-online.rivm.nl/

27. Dekkers AL, Verkaik-Kloosterman J, Slob W et al. (2012) SPADE: a statistical program to assess dietary exposure. In Abstract Book of the 8th International Conference on Diet and Activity Methods: Methodological Challenges for Measuring the Cabievments of International Policy, Rome, 14-17 May 2012, p. 156. Rome: FAO.

28. Wallén A, Brandt N \& Wennersten R (2004) Does the Swedish consumer's choice of food influence greenhouse gas emissions? Environ Sci Policy 7, 525-535.

29. World Health Organization (2003) Diet, Nutrition and the Prevention of Chronic Diseases. Joint WHO/FAO Expert Consultation. WHO Technical Report Series no. 916. Geneva: WHO.

30. van Kreijl CF, Knaap AGAC \& van Raaij JMA (2006) Our Food Our Health. RIVM Report no. 270555009. Bilthoven: RIVM.

31. Mozaffarian D \& Capewell S (2011) United Nations' dietary policies to prevent cardiovascular disease. BMJ 343, d5747.

32. Mensink GB, Fletcher R, Gurinovic M et al. (2013) Mapping low intake of micronutrients across Europe. Br J Nutr 110, $755-773$

33. Temme E, van der Voet H, Thissen J et al. (2013) Replacement of meat and dairy by plant-derived foods: estimated effects on land use, iron and SFA intakes in young Dutch adult females. Public Health Nutr 16, 1900-1907.

34. Ludwig DS, Peterson KE \& Gortmaker SL (2001) Relation between consumption of sugar-sweetened drinks and childhood obesity: a prospective, observational analysis. Lancet 357, 505-508.

35. de Ruyter JC, Olthof MR, Seidell JC et al. (2012) A trial of sugar-free or sugar-sweetened beverages and body weight in children. $N$ Engl J Med 367, 1397-1406.

36. van Oel PR, Mekonnen MM \& Hoekstra AY (2009) The external water footprint of the Netherlands: geographicallyexplicit quantification and impact assessment. Ecol Econ 69, 82-92.

37. Freisling H, van Bakel MM, Biessy C et al. (2012) Dietary reporting errors on $24 \mathrm{~h}$ recalls and dietary questionnaires are associated with BMI across six European countries as evaluated with recovery biomarkers for protein and potassium intake. Br J Nutr 107, 910-920. 